\title{
Hepatic Expression of Cu/Zn-Superoxide Dismutase Transcripts in Response to Acute Metal Exposure and Heat Stress in Hemibarbus mylodon (Teleostei: Cypriniformes)
}

\author{
Young Sun Cho, In-Chul BANG ${ }^{\prime}$, Il-Ro LeE ${ }^{1}$ and Yoon Kwon NAM* \\ Department of Aquaculture \& Institute of Marine Living Modified Organisms, \\ Pukyong National University, Busan 608-737, Korea \\ ${ }^{1}$ Department of Marine Biotechnology, Soonchunhyang University, Asan 336-745, Korea
}

\begin{abstract}
Hemibarbus mylodon (Cypriniformes) is an endemic freshwater fish species in the Korean peninsula, for which urgent conservation efforts are needed. To understand their stress responses in relation to metal toxicity and thermal elevation, we performed a real-time RT-PCR-based expression assay of hepatic copper/zinc-superoxide dismutase ( $\mathrm{Cu} / \mathrm{Zn}$-SOD), a key antioxidant enzyme, in response to experimental heavy metal exposure or heat treatment. The transcription of hepatic $\mathrm{Cu} / \mathrm{Zn}-\mathrm{SOD}$ was differentially modulated by acute exposure to $\mathrm{Cu}$, cadmium $(\mathrm{Cd})$, or $\mathrm{Zn}$. Exposure to each metal at $5 \mu \mathrm{M}$ for $24 \mathrm{~h}$ revealed that $\mathrm{Cu}$ stimulated the mRNA expression of $\mathrm{Cu} / \mathrm{Zn}-\mathrm{SOD}$ to a greater extent than the other two heavy metals. The elevation in $\mathrm{Cu} / \mathrm{Zn}-\mathrm{SOD}$ transcripts in response to $\mathrm{Cu}$ exposure was dose-dependent $(0.5$ to $5 \mu \mathrm{M})$. Time course analysis of $\mathrm{Cu} / \mathrm{Zn}$-SOD expression in response to $\mathrm{Cd}$ exposure $(5 \mu \mathrm{M})$ revealed a transient pattern up to day 7. Exposure to thermal stress (an increase from 22 to $30^{\circ} \mathrm{C}$ at a rate of $1{ }^{\circ} \mathrm{C} / \mathrm{h}$ followed by $30^{\circ} \mathrm{C}$ for $18 \mathrm{~h}$ ) did not significantly alter SOD transcription, although heat shock protein $90 \mathrm{kDa}$ (HSP90) transcription was positively correlated with an increase in temperature.
\end{abstract}

Key words: Cu/Zn-SOD, Hemibarbus mylodon, Heavy metals, Heat stress, Gene expression

\section{Introduction}

Over the last decade, the natural habitat of Hemibarbus mylodon (Teleostei: Cypriniformes), an endemic species in the Korean peninsula, has been significantly disturbed by various anthropogenic activities; as a result, this species is considered an endangered organism with a high risk of extinction (Cho et al., 2008; Kim et al., 2008). Furthermore, the results of two recent molecular analyses indicated that the genetic diversity of currently existing $H$. mylodon populations is extremely low (Kim et al., 2007a; Lee et al., 2008). Thus, conservation and restoration efforts are urgently needed for this species. For the in situ and ex situ restoration of threatened fish species, a biomarker-assisted understanding of stress physiology at the cellular level is invaluable in the designation of conservation plans.

Copper/zinc-superoxide dismutase $(\mathrm{Cu} / \mathrm{Zn}-\mathrm{SOD}$; EC 1.15.1.1) is a key antioxidant enzyme with roles

\footnotetext{
*Corresponding author: yoonknam@pknu.ac.kr
}

in the first line of defense against oxidative stress caused by reactive oxygen species (ROS) (Zelko et al., 2002). Due to its essential function, $\mathrm{Cu} / \mathrm{Zn}-\mathrm{SOD}$ is known as a housekeeper in most aerobic cell types. However, despite its essential function, the expression of $\mathrm{Cu} / \mathrm{Zn}-\mathrm{SOD}$ at both the mRNA and protein levels is known to be modulated by several biotic (e.g., disease or physiological states) and abiotic factors (e.g., environmental pollutants), since those stimulatory factors may enhance the formation of ROS in animal tissues (Cho et al., 2006; Hansen et al., 2006; Kim et al., 2007b). Consequently, studies have proposed that $\mathrm{Cu} / \mathrm{Zn}$-SOD be used as a nonspecific biomarker to warn of and/or detect physiological alterations in animals and environmental problems associated with pollution (Almeida et al., 2002; Kunikowska and Jenner, 2003; Pandey et al., 2003; Nam et al., 2005).

The objective of this study was to examine the transcriptional response of hepatic $\mathrm{Cu} / \mathrm{Zn}$-SOD to acute metal exposure or heat stress in $H$. mylodon to evaluate the potential usefulness of $\mathrm{Cu} / \mathrm{Zn}-\mathrm{SOD}$ 
mRNA as a candidate biomarker of oxidative stress in this species.

\section{Materials and Methods}

\section{Fish specimen and $\mathrm{Cu} / \mathrm{Zn}-\mathrm{SOD}$ cDNA}

The fish specimen used in this study was obtained from a laboratory stock maintained at Soonchunhayng University (Asan, Korea). The general conditions of fish management were as described in Bang et al. (2007a). The $\mathrm{Cu} / \mathrm{Zn}-\mathrm{SOD}$ clone was isolated as part of a previous expressed sequence tag (EST) analysis (Bang et al., 2007b); its full-length cDNA sequence is available from the NCBI GenBank database under accession number FJ975147. The $H$. mylodon heat shock protein $90 \mathrm{kDa}$ (HSP90) clone, which was employed as a quality control to validate the effectiveness of the thermal regime used in this study, was a partial cDNA clone identified from the same EST database (Nam YK, unpublished data).

\section{Acute heavy metal exposure}

The transcriptional modulation of $\mathrm{Cu} / \mathrm{Zn}-\mathrm{SOD}$ was examined using a series of acute metal exposure experiments. First, to examine the potency of different metals for the stimulation of $\mathrm{Cu} / \mathrm{Zn}$-SOD transcripttion, juvenile fish (average body weight, $10.3 \pm 1.2 \mathrm{~g}$ ) were exposed to a given concentration $(5 \mu \mathrm{M})$ of waterborne heavy metals. The fish $(n=18)$ were allocated to one of two replicate tanks containing 50 $\mathrm{L}$ of well aerated (dissolved oxygen $=5 \pm 1 \mathrm{ppm}$ ) tap water. After this period, the experimental groups were exposed to a nominal concentration $(5 \mu \mathrm{M})$ of cadmium $(\mathrm{Cd}), \mathrm{Cu}$, or $\mathrm{Zn}$ using $0.5 \mathrm{M}$ stock solutions of $\mathrm{CdCl}_{2}, \mathrm{CuCl}_{2}$, or $\mathrm{ZnCl}_{2}$, respectively. The metal reagents were of analytical grade (Sigma, St. Louis, MO, USA). Control groups were prepared, which were identical except for the addition of the heavy metals. The water was kept at $22 \pm 1{ }^{\circ} \mathrm{C}$ throughout the experiment. After $24 \mathrm{~h}$, six individuals were randomly selected from each tank, and the livers were surgically obtained for RT-PCR analysis. Second, fish were exposed to different levels of $\mathrm{Cu}$ or $\mathrm{Cd}$ to examine the interrelationship between dose strength and the expression of SOD. Twelve individuals of the same size class as above were immersed in $\mathrm{Cu}(0,0.5$, $1,2$, or $5 \mu \mathrm{M})$ or $\mathrm{Cd}(0,1,2,5$, or $10 \mu \mathrm{M})$ for $24 \mathrm{~h}$, and the hepatic SOD mRNA levels were examined in five individuals randomly chosen from each tank. All other conditions were as described above. Third, $H$. mylodon individuals were exposed to $\mathrm{Cd}$ for different durations $(1,2,4$, and 7 days). Fifteen individuals were allocated to each of 50 -L tanks containing $5 \mu \mathrm{M}$
Cd. Non-exposed controls were also prepared. The water exchange rate was $50 \%$ per day, and the metal was renewed at the time of each water change. Three individuals were randomly obtained from each tank at each detection point. The liver was removed from each individual, pooled within the group, and subjected to RNA extraction for RT-PCR analysis.

\section{Experimental heat stress}

Fish were exposed to a thermal regime to examine whether the mRNA expression of SOD is affected by heat stress. Using fish $(4.5 \pm 1.2 \mathrm{~g}$ body weight $)$ that had been maintained in a tank $(200 \mathrm{~L})$ at $22 \pm 1^{\circ} \mathrm{C}, 30$ individuals were transferred to one of two 50 - $\mathrm{L}$ tanks containing well aerated water (dissolved oxygen= $5.0 \pm 1.5 \mathrm{ppm}$ ) at $22^{\circ} \mathrm{C}$. The fish were allowed to acclimate for $24 \mathrm{~h}$. Afterward, the water temperature of one tank was raised to $30^{\circ} \mathrm{C}$ at a rate of $1{ }^{\circ} \mathrm{C} / \mathrm{h}$ using an electrically controlled heating device, whereas the other tank was kept at $22^{\circ} \mathrm{C}$ (control group). The fish $(n=4)$ were sampled at the starting point $\left(22^{\circ} \mathrm{C}\right)$ and at $4\left(26^{\circ} \mathrm{C}\right), 8\left(30^{\circ} \mathrm{C}\right), 14(6 \mathrm{~h}$ after reaching $\left.30^{\circ} \mathrm{C}\right), 20\left(12 \mathrm{~h}\right.$ after reaching $\left.30^{\circ} \mathrm{C}\right)$, and 26 $\mathrm{h}\left(18 \mathrm{~h}\right.$ after reaching $\left.30^{\circ} \mathrm{C}\right)$ post-temperature elevation. At the same time, an equal number of fish was sampled from the control tank $\left(22^{\circ} \mathrm{C}\right)$. Livers were surgically obtained, pooled within the group prior to RNA extraction, and used for RT-PCR analysis.

\section{Real-time RT-PCR assay}

Total RNA was purified from each liver using an RNeasy Mini Kit (Qiagen, Hilden, Germany) according to the manufacturer's recommendations plus DNase treatment. For real-time RT-PCR, $4 \mu \mathrm{g}$ of purified total RNA was reverse transcribed at $37^{\circ} \mathrm{C}$ for $60 \mathrm{~min}$ in a $40-\mu \mathrm{L}$ reaction volume using Omniscript RTase (Qiagen) and oligo d(T) $)_{20}$ primer (1 $\mu \mathrm{M}$ final concentration). To prepare the normalization control, Fi18S rRNA 1R primer (5'-CAAGAATTTCA CCTCTAGCGGC-3'), a conserved reverse primer for fish 18S rRNA, was included in the RT reaction at 0.1 $\mu \mathrm{M}$ for coapplication reverse transcription (Co-RT) (Zhu and Altmann, 2005). When the reaction was finished, the product was diluted twofold with sterile water and $1 \mu \mathrm{L}$ of the diluted cDNA was subjected to real-time PCR. Standard curves of the target (SOD) and control (18S rRNA) were prepared as threshold cycles versus the log number of positive cDNA templates (Schmittgen and Livak, 2008). The primers used were the following: $\mathrm{HM} \mathrm{Cu/Zn-SOD} 1 \mathrm{~F}$ (5'CGCACTTCAACCCTCACAAT-3') and HMCu/ZnSOD 1R (5'-CTCTACCCAGTGATGCCAAT- $\left.3^{\prime}\right)$ for $\mathrm{Cu} / \mathrm{Zn}$-SOD, and HM18S 1F (5'-AGAAACGGCTAC 
CACATCCA-3') and HM18S rRNA 1R (5'-GGAC ACCCAGTTAAGGGCAT-3') for the 18S rRNA control (Nam YK, unpublished data). The expected sizes of the products were 280 and 338 bp for SOD and $18 \mathrm{~S}$ rRNA, respectively. PCR primers, qHMhsp90 1F (5'-ATGAAGACGTGCCTGTGGAA$\left.3^{\prime}\right)$ and qHMhsp90 1R (5'-AGACAATACTGCAGC AACCC $-3^{\prime}$ ) were used to amplify 330 bp from the $H$. mylodon HSP90 cDNA fragments as a control. Reaction volume was $25 \mu \mathrm{L}$. The reaction included iQ SYBR Green Supermix (Bio-Rad, Hercules, CA, USA) and was run with the iCycler iQ Real-Time Detection System (Bio-Rad). An initial incubation at $95^{\circ} \mathrm{C}$ for $5 \mathrm{~min}$ was followed by 45 cycles of $20 \mathrm{~s}$ at $94^{\circ} \mathrm{C}, 20 \mathrm{~s}$ at $58^{\circ} \mathrm{C}$, and $25 \mathrm{~s}$ at $72^{\circ} \mathrm{C}$ for all three transcripts. Fluorescence readings were taken at $72^{\circ} \mathrm{C}$ after each cycle to calculate the average threshold cycles $\left(\mathrm{C}_{\mathrm{t}}\right)$. The level of SOD mRNA in each sample was normalized against its own level of $18 \mathrm{~S}$ rRNA, and the fold-changes in SOD transcription in the treated group relative to the untreated controls were estimated using the $2^{-\Delta \Delta \mathrm{Ct}}$ method (Schmittgen and Livak, 2008).

\section{Statistics}

Triplicate real-time RT-PCR was performed per cDNA sample in an independent manner. The relative mRNA levels of SOD were assessed by ANOVA followed by Duncan's multiple range tests. If needed, Student's $t$-test was used to examine the statistical difference between the stimulated and control groups. Differences were considered to be significant at $P<0.05$.

\section{Results and Discussion}

The viability of the experimental groups did not differ under the present exposure conditions $(P>0.05$, data not shown); however, the hepatic mRNA expression of $\mathrm{Cu} / \mathrm{Zn}$-SOD was readily influenced by exogenously administered heavy metal ions. The standard curves prepared in our real-time PCR analysis were fairly close to linear, with linearity coefficients $\geq 0.991$ for both the target (SOD) and control (18S rRNA) genes. The expression of the $18 \mathrm{~S}$ rRNA control was without notable fluctuations, regardless of the experimental group $\left(C_{t}\right.$ values ranging from 13.3 to 13.8 ). At $5 \mu \mathrm{M}, \mathrm{Cu}$ was more potent than the other metals in terms of the increase in hepatic $\mathrm{Cu} / \mathrm{Zn}-\mathrm{SOD}$ transcription. $\mathrm{Cu} / \mathrm{Zn}-\mathrm{SOD}$ expression in the $\mathrm{Cu}$-exposed group was 3.8 times the level in the unexposed (control) group. $\mathrm{Cd}$ exposure also moderately induced $\mathrm{Cu} / \mathrm{Zn}$-SOD transcription up to 1.7-fold, whereas $\mathrm{Zn}$ did not alter the mRNA level of $\mathrm{Cu} / \mathrm{Zn}$-SOD (Fig. 1A). Our finding of $\mathrm{Cu} / \mathrm{Zn}$-SOD stimulation in response to metal exposure is congruent with previous reports in other fish species (Pandey et al., 2003; Cho et al., 2006; Nam et al., 2006), suggesting that heavy metals are a strong prooxidative factor. The differential effects of the metals on the expression of metal-binding proteins could be explained by the metal-specific accumulation rate, which is associated with the amount of binding ligands, the influx/efflux rate, and the tissuespecific availability of each metal ion (Kock et al., 1995; Maes et al., 2005). One possible, but undefined, explanation for the lack of stimulated expression in the $\mathrm{Zn}$-exposed fish is that other $\mathrm{Zn}$-binding proteins, particularly metallothioneins (major reservoirs of intracellular $\mathrm{Zn}$ ), might bind the $\mathrm{Zn}$ competitively, thereby diminishing the $\mathrm{Zn}$-mediated tissue burden and forestalling the need for additional $\mathrm{Cu} / \mathrm{Zn}-\mathrm{SOD}$ transcription in the liver. Furthermore, our relatively short exposure period $(24 \mathrm{~h})$ despite the high treatment concentration may also explain this finding (see Haq et al., 2003). However, a comparative expression analysis of $\mathrm{Cu} / \mathrm{Zn}$-SOD along with other zinc-binding proteins (e.g., MTs) for an extended period should be carried out in the future.

In the second exposure experiment utilizing varying concentrations of $\mathrm{Cu}(0.5$ to $5 \mu \mathrm{M})$ or $\mathrm{Cd}(1$ to $10 \mu \mathrm{M})$, the expression pattern of $\mathrm{Cu} / \mathrm{Zn}-\mathrm{SOD}$ was different between the two heavy metal-treated groups. With $\mathrm{Cu}$, a rise in hepatic $\mathrm{Cu} / \mathrm{Zn}$-SOD transcription was observed at all four doses, and the increase was fairly dose-dependent $(P<0.05)$. On the other hand, $\mathrm{Cd}$ upregulated the mRNA expression of $\mathrm{Cu} / \mathrm{Zn}-\mathrm{SOD}$ at 5 and $10 \mu \mathrm{M}$ but not at lower doses $(1$ and $2 \mu \mathrm{M}$; Fig. 1B). Furthermore, no dose-dependency was observed between the 5 and $10 \mu \mathrm{M}$-treated groups. This result (i.e., the preferential induction of SOD by $\mathrm{Cu}$ ) suggests that the accumulation rate of $\mathrm{Cd}$ in the liver might be slower than that of $\mathrm{Cu}$ in $\mathrm{H}$. mylodon livers; a longer duration should be tested to validate this preliminary finding. A study previously reported that SOD activity could be "saturated" without further elevation by increasing the dose of $\mathrm{Cd}$ (Almeida et al., 2002).

From the Cd-exposure experiment used to examine the effects of treatment duration ( $5 \mu \mathrm{M}$ up to 7 days) on SOD expression, the control group showed no significant fluctuation in the hepatic level of $\mathrm{Cu} / \mathrm{Zn}$ SOD transcription during the experimental period. On the other hand, the expression of $\mathrm{Cu} / \mathrm{Zn}-\mathrm{SOD}$ in fish exposed to $\mathrm{Cd}$ was upregulated as early as day 1 (1.9fold; $P<0.05$ ), further stimulated at day 4 (4.2-fold; 


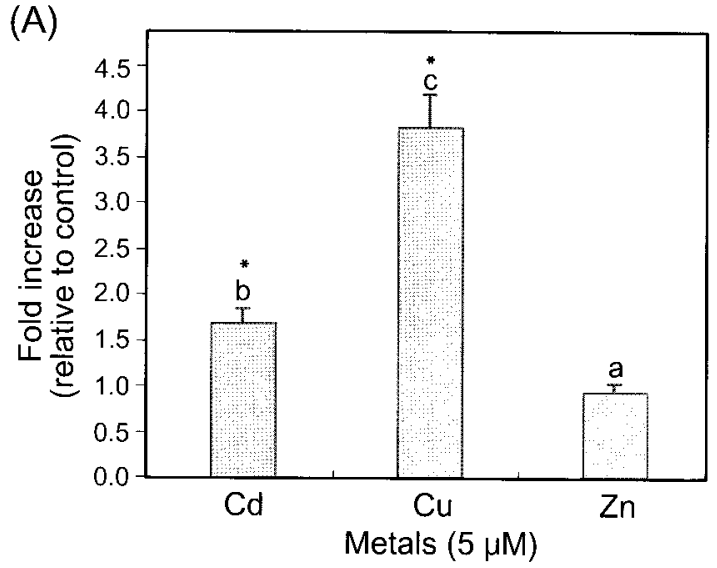

(B)

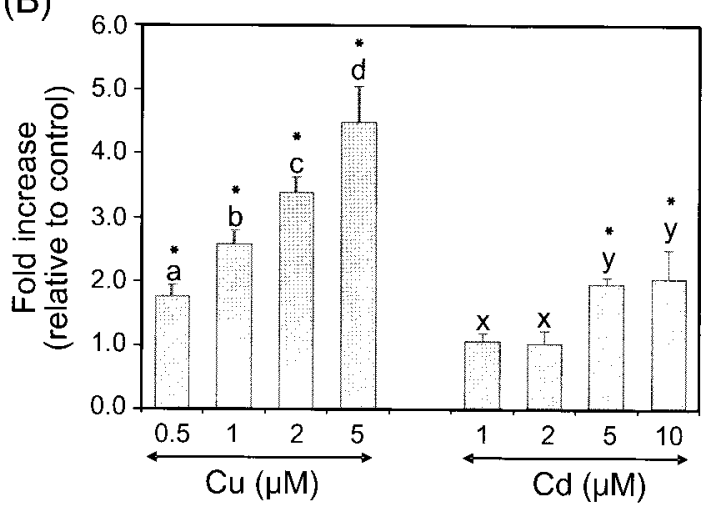

Fig. 1. Effects of heavy metal exposure on the hepatic expression of Hemibarbus mylodon $\mathrm{Cu} / \mathrm{Zn}-\mathrm{SOD}$ transcripts. A: Expression of $\mathrm{Cu} / \mathrm{Zn}-\mathrm{SOD}$ in fish exposed to three different heavy metals $(\mathrm{Cd}, \mathrm{Cu}$, or $\mathrm{Zn}$ ) at $5 \mu \mathrm{M}$ for $24 \mathrm{~h}$. B: Transcriptional response of $\mathrm{Cu} / \mathrm{Zn}-\mathrm{SOD}$ to various doses of $\mathrm{Cu}(0.5$ to $5 \mu \mathrm{M})$ or $\mathrm{Cd}(1$ to $10 \mu \mathrm{M})$ for $24 \mathrm{~h}$. By real-time RT-PCR analysis, the relative $\mathrm{mRNA}$ level expression of SOD was estimated by normalization against the $18 \mathrm{~S}$ rRNA control; it is expressed as the fold-increase relative to that in the control groups. The means \pm SD based on triplicate examinations are shown as histograms with T-bars. Means with different letters (a-c in $\mathrm{A}$ and $\mathrm{a}-\mathrm{d}$ or $\mathrm{x}-\mathrm{y}$ in $\mathrm{B}$ ) were significantly different when assessed by ANOVA $(P<0.05)$. The means indicated by asterisks are significantly different from the basal level in the control group (Student's $t$-test, $P<0.05)$.

$P<0.05)$, and then returned to the control level at day 7 ( $P>0.05$; Fig. 3). The diminished expression or even inverse regulation of antioxidant enzymes has been reported following acute exposure to relatively high concentrations of heavy metals (Geret et al., 2002; Matz et al., 2006; Nam et al., 2006). This phenomenon may be associated with the acclimation process following an initial shock phase, in which the physiology establishes a new steady state (McDonald

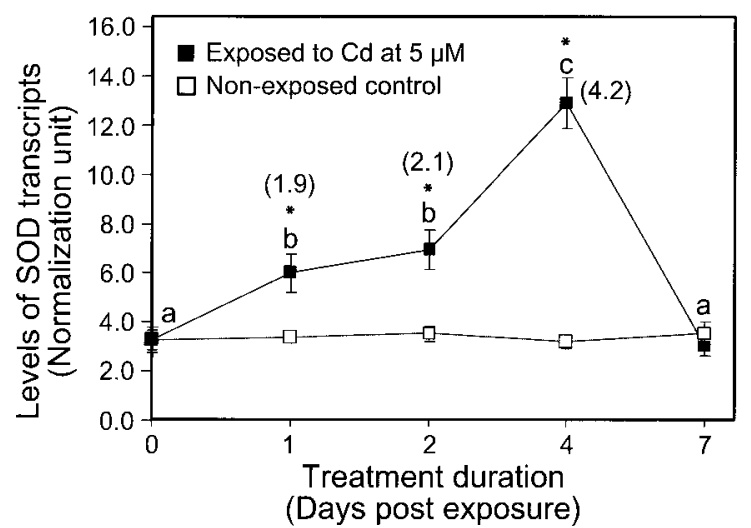

Fig. 2. Time course of $\mathrm{Cu} / \mathrm{Zn}-\mathrm{SOD}$ mRNA expression in the liver of Hemibarbus mylodon exposed to $5 \mu \mathrm{M}$ $\mathrm{Cd}$ for $1,2,4$, and 7 days. The controls showed no notable fluctuation in SOD expression regardless of the time point (ANOVA, $P>0.05$ ). Significantly different means (ANOVA, $P<0.05$ ) are indicated by different letters (a-c). Means showing a significant difference from the controls are noted by asterisks (Student's $t$-test, $P<0.05$ ); the fold-increases (relative to the control values) at days 1,2 , and 4 are noted in parentheses.

and Wood, 1993; Hansen et al., 2006). Alternatively, such a decrease could result from detrimental effects related to increased stress, in which the intensity of stress is beyond the regulatory capacity such that the fish reach a stage of exhaustion (Guecheva et al., 2003).

During heat treatment, the quality control, HSP90, was significantly upregulated during Phases I (from 22 to $30^{\circ} \mathrm{C}$ at $1^{\circ} \mathrm{C} / \mathrm{h}$ ) and II (6 to $18 \mathrm{~h}$ after reaching $30^{\circ} \mathrm{C}$ ) of the thermal regime. The maximum foldincrease in HSP90 expression was 7.6 relative to the control group (maintained continuously at $22^{\circ} \mathrm{C}$ ) as assessed by real-time PCR analysis. However, in contrast, the level of $\mathrm{Cu} / \mathrm{Zn}$-SOD transcription was not altered during the elevation or the static incubation phase $(P>0.05$; Fig. 3). This was unexpected since the temperature applied in the present study $\left(30^{\circ} \mathrm{C}\right)$ was higher than the generally agreed optimum temperature for $H$. mylodon culture (about $24-25^{\circ} \mathrm{C}$ ). Water temperature is the primary abiotic factor modulating various physiological pathways in poikilothermal animals, and thermal stress is believed to be one cause of oxidative stress in those organisms (Buckley et al., 2006; Kim et al., 2007b). The lack of a transcriptional response by SODs to heat stress in the present study may have been due to the relatively short period of exposure, which might be insufficient for generating excessive ROS to be scavenged by SODs. Many previous studies have reported that the 


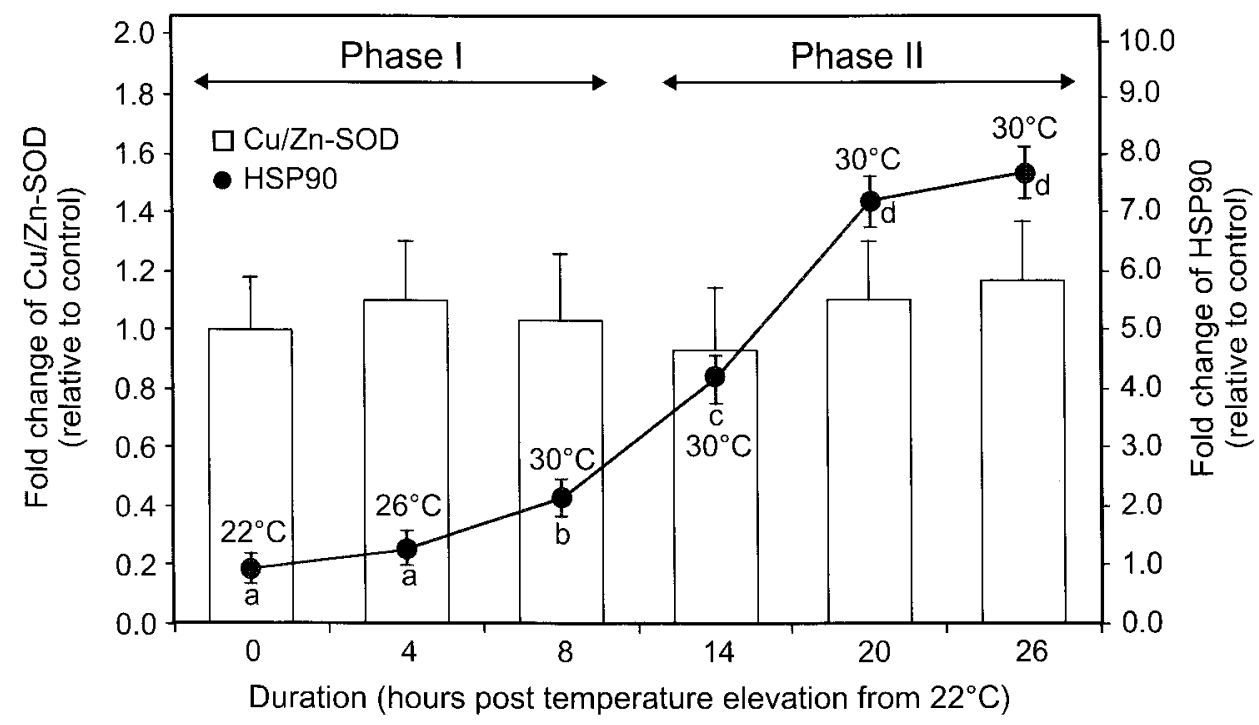

Fig. 3. Expression of $\mathrm{Cu} / \mathrm{Zn}-\mathrm{SOD}$ and HSP90 transcripts during thermal treatment. In Phase I, the water temperature was elevated from 22 to $30^{\circ} \mathrm{C}$ at a rate of $1{ }^{\circ} \mathrm{C} / \mathrm{h}$; fish were sampled immediately when the temperature reached the desired point $\left(22,26\right.$, and $\left.30^{\circ} \mathrm{C}\right)$. In Phase II, the water temperature was maintained at $30^{\circ} \mathrm{C}$ for $18 \mathrm{~h}$. During Phase II, fish were sampled at 6-h intervals. No significant alteration was observed in $\mathrm{Cu} / \mathrm{Zn}$-SOD whereas a notable elevation was detected in HSP90. Means (HSP90) with different letters are significantly different based on ANOVA/Duncan's test $(P=0.05)$.

most responsive proteins to the acute phase of heat stress in teleosts are HSPs rather than SOD (Murtha and Keller, 2003; Deane and Woo, 2005; Buckley et al., 2006). Our examination of the profound upregulation of H. mylodon HSP90 mRNA under the same experimental conditions (particularly in Phase II; Fig. 3 ) is also, at least in part, supportive of this explanation. Hence, further study to examine the expression of SODs along with other heat stress-responsive proteins following extended thermal treatment are needed to elucidate the cross talk between SODs and other heat stress-related proteins.

In summary, the transcriptional response of $\mathrm{Cu} / \mathrm{Zn}$ SOD to stimulation with heavy metals and heat was examined in the liver of H. mylodon, a threatened fish species. The results of this study can be used to evaluate $\mathrm{Cu} / \mathrm{Zn}$-SOD as a candidate biomarker for the altered physiology of $H$. mylodon in response to toxic pollutants. However, additional studies should be initiated to test the effects of other biotic and abiotic factors on the expression of SOD under more environmentally robust conditions.

\section{Acknowledgments}

This study was supported by funds from the Korea Foundation for International Cooperation of Science and Technology.

\section{References}

Almeida, J.A., Y.S. Diniz, S.F.G. Marques, L.A. Faine, B.O. Ribas, B.C. Burneiko and E.L.B. Novelli. 2002. The use of the oxidative stress responses as biomarkers in Nile tilapia (Oreochromis Uniloticus) exposed to in vivo cadmium contamination. Environ. Intl., 27, 673679.

Bang, I.C., Y.S. Cho, I.R. Lee and Y.K. Nam. 2007a. Effects of acute metal exposures on the viability and mRNA expression of metallothionein in Hemibarbus mylodon fry. Kor. J. Limnol., 40, 489-494.

Bang, I.C., Y.H. Lim, Y.S. Cho, S.Y. Lee and Y.K. Nam. 2007b. Survey of expressed sequence tags from tissue-specific cDNA libraries in Hemibarbus mylodon, an endangered fish species. J. Aquacult., 20, 248-254.

Buckley, B.A., A.Y. Gracey and G.N. Somero. 2006. The cellular response to heat stress in the goby Gillichthys mirabilis: a cDNA microarray and protein-level analysis. J. Exp. Biol., 209, 2660-2677.

Cho, Y.S., B.N. Choi, K.H. Kim, S.K. Kim, D.S. Kim, I.C. Bang and Y.K. Nam. 2006. Differential expression of $\mathrm{Cu} / \mathrm{Zn}$ superoxide dismutase mRNA during exposures to heavy metals in rockbream (Oplegnathus fasciatus). Aquaculture, 253, 667-679.

Cho, Y.S., S.Y. Lee, K.Y. Kim, I.C. Bang, D.S. Kim and Y.K. Nam. 2008. Gene structure and expression of metallothionein during metal exposures in Hemibarbus 
mylodon. Ecotoxicol. Environ. Saf., 71, 125-137.

Deane, E.E. and N.Y. Woo. 2005. Cloning and characterization of the hsp70 multigene family from silver sea bream: Modulated gene expression between warm and cold temperature acclimation. Biochem. Biophys. Res. Commun., 330, 776-783.

Geret, F., A. Serafim, L. Barreira and M.J. Bebianno. 2002. Response of antioxidant systems to copper in the gills of the clam, Ruditapes decussatus. Mar. Environ. Res., 54, 413-417.

Guecheva, T.N., B. Erdtmann, M.S. Benfato and J.A.P. Henriques. 2003. Stress protein response and catalase activity in freshwater planarian Dugesia (Girardia) schubarti exposed to cooper. Ecotoxicol. Environ. Saf., 56, 351-357.

Hansen, B.H., S. Romma, O.A. Garmo, P.A. Olsvik and R.A. Andersen. 2006. Antioxidative stress proteins and their gene expression in brown trout (Salmo trutta) from three rivers with different heavy metal levels. Comp. Biochem. Physiol., 143C, 263-274.

Haq, F., M. Mahoney and J. Koropatnick. 2003. Signaling events for metallothionein induction. Mutation Res., 533, 211-266.

Kim, K.Y., S.Y. Lee, Y.S. Cho, I.C. Bang, D.S. Kim and Y.K. Nam. 2008. Characterization and phylogeny of two $\beta$-cytoskeletal actins from Hemibarbus mylodon (Cyprinidae, Cypriniformes), a threatened fish species in Korea. DNA Seq., 19, 87-97.

Kim, K.Y., S.Y. Lee, Y.S. Cho, I.C. Bang, K.H. Kim, D.S. Kim and Y.K. Nam. 2007b. Molecular characterization and mRNA expression during metal exposure and thermal stress of copper/zinc- and manganese-superoxide dismutases in disk abalone, Haliotis discus discus. Fish Shellfish Immunol., 23, 1043-1059.

Kim, Y.J., Y.A. Lee and I.C. Bang. 2007a. Isolation and characterization of polymorphic microsatellite markers for the endangered Korean freshwater fish Hemibarbus mylodon. Mol. Ecol. Notes, 7, 516-518.

Kock, G., R. Hoper and S. Wograth. 1995. Accumulation of trace metals $\mathrm{Cd}, \mathrm{Pb}, \mathrm{Cu}, \mathrm{Zn}$ in arctic char Salvelinus alpinus from oligotrophic alpine lakes: relation to alkalinity. Can. J. Fish. Aquat. Sci., 52, 2367-2376.

Kunikowska, G. and P. Jenner. 2003. Alterations in m-RNA expression of $\mathrm{Cu}, \mathrm{Zn}$-superoxide dismutase and glutathione peroxidase in the basal ganglia of MPTPtreated marmosets and patients with Parkinson's disease. Brain Res., 968, 206-218.

Lee, Y.A., Y.E. Yun, Y.K. Nam and I.C. Bang. 2008. Genetic diversity of endangered fish Hemibarbus mylodon (Cyprinidae) assessed by AFLP. J. Aquacult., 21, 196-200.

Maes, G.E., J.A.M. Raeymaekers, C. Pampoulie, A. Seynaeve, G. Goemans, C. Belpaire and F.A.M. Volckaert. 2005. The catadromous European eel Ancuilla anguilla (L.) as a model for freshwater evolutionary ecotoxicology: Relationship between heavy metal bioaccumulation, condition and genetic variability. Aquatic Toxicol., 73, 99-114.

Matz, C.J., R.G. Treble and P.H. Krone. 2006. Accumulation and elimination of cadmium in larval stage zebrafish following acute exposure. Ecotoxicol. Environ. Saf., 66, 44-48.

McDonald, D.G. and C.M. Wood. 1993. Branchial mechanisms of acclimation to metals in freshwater fish. In: Fish Ecophysiology. Rankin, J.C. and F.B. Jensen, eds. Chapman and Hall. U.S.A., 479-608.

Murtha, J.M. and E.T. Keller. 2003. Characterization of the heat shock response in mature zebrafish (Danio rerio). Exp. Gerontol., 38, 683-691.

Nam, Y.K., Y.S. Cho, B.N. Choi, K.H. Kim, S.K. Kim and D.S. Kim. 2005. Alteration of antioxidant enzymes at the mRNA level during short-term starvation of rockbream Oplegnathus fasciatus. Fish. Sci., 71, 1385-1387.

Nam, Y.K., Y.S. Cho, K.Y. Kim, I.C. Bang, K.H. Kim, S.K. Kim and D.S. Kim. 2006. Characterization of copper, zinc superoxide dismutase from a cartilaginous shark species, Scyliorhinus torazame (Carcharhiniformes). Fish Physiol. Biochem., 32, 305-315.

Pandey, S., S. Parvez, I. Sayeed, R. Haque, B. Bin-Hafeez and S. Raisuddin. 2003. Biomarkers of oxidative stress: a comparative study of river Yamuna fish Wallago attu (B1. \& Schn.). Sci. Total Environ., 309, 105-115.

Schmittgen, T.D. and K.J. Livak. 2008. Analyzing realtime PCR data by the comparative CT method. Nat. Protoc., 3, 1101-1108.

Zelko, I.N., T.J. Mariani and R.J. Folz. 2002. Superoxide dismutase multigene family: a comparison of the CuZn-SOD (SOD1), Mn-SOD (SOD2), and EC-SOD (SOD3) gene structures, evolution, and expression. Free Radic. Biol. Med., 33, 337-349.

Zhu, L.J. and S.W. Altmann. 2005. mRNA and 18S-RNA coapplication-reverse transcription for quantitative gene expression analysis. Anal. Biochem., 345, 102109.

(Received 30 April 2009; Revised 15 May 2009; Accepted 27 May 2009) 